\title{
A STUDY ON IMPACT OF SOCIAL MEDIA ON WOMEN EMPOWERMENT IN INDIA
}

\author{
Amit Kumar Mandal \\ MBA Student, Department of Business Administration, NIT, Kurukshetra, Haryana.
}

Article DOI: https://doi.org/10.36713/epra9558

DOI No: 10.36713/epra9558

\begin{abstract}
The development of technology and therefore the increasing dependence on that over the years, has had an on the spot impact on women empowerment. Social media has become a robust tool of digital media and has worked towards increasing the communication network across the planet. within the inside of the continued pandemic, the importance of those digital platforms has doubled. Social media and social policy become extremely reticulate over the past few years. Social media has given a platform to women to debate their problems, opinions, views through blogs, discussion forums, on-line campaigns, chats etc. This paper highlights however social media are often constructively want to achieve women empowerment within the society. It conjointly discusses the execs and cons of the excessive dependence on the social media platforms within the path of women empowerment. This paper is split into five sections. The importance of social media deals with the first part and how different social media platforms have become so prominent over the last few years. The second sections deals with the which means and idea of women empowerment. The third section analyses however social media has compact the lives of the women and how it has become a tool of women empowerment. The fourth section covers the disadvantage faced by these social media and platforms and what steps needed to be taken to block these Issues. The last section concludes the theoretical findings of this paper.
\end{abstract}

INDEX TERMS—media platforms, women empowerment, Social change, digital gender stereotypes.

\section{INTRODUCTION}

Our fundamental rights were granted to us under Part III of the Constitution in mid-20th century i.e., within the age of print and tv media however now days each single individual has access to the news with the assistance of digital and social media platforms. Article 19 of the Indian Constitution entitles each Indian citizen to the freedom of speech and expression. The world has become a global village and the social media networking websites are playing a crucial role in connecting people across the globe. Media is now emerging as an important fourth pillar of democracy along with legislature, executive and judiciary. In the present day world, social media has become a medium of social modification. The mix of social media and net has developed a brand new kind of media that has considerably boomed during a last decade or two. Not only does the social media platforms help in connecting the individuals, but it also acts as a powerful agent to bring about women empowerment in the society by mobilizing the attention of the masses towards the long prevailing stereotypes. The development of social media platforms has opened a plethora of opportunities for the women. Social media platforms like Facebook, Twitter, Instagram,
Snapchat, YouTube etc. have emerged as important networks that are being widely used to raise awareness amongst the masses. Social media has given women and activists a platform to openly express their opinions and thoughts when their views are mostly restricted by the societal norms. It acts as an alternative medium to raise important issues of concern for the women. Just being able to raise their views at a finger tap, gives women a certain amount of sense of freedom, something that they had not experienced over the centuries.

G. Padmaja in the article 'Media's Role in the Empowerment of Women in India' (2017) analyses how women empowerment helps in the overall development of the lives of the women and how the media helps in breaking the stereotypes and sex barriers.

\section{WOMEN EMPOWERMENT}

Women represent or so $50 \%$ of the Indian population of one hundred fifty crores. In terms of rights, they need become nearly adequate to their male counterparts over the previous few years. however has legal equality caused empowerment of women within the real sense? The term empowerment can be associated to the concept of power. Empowerment is necessary 
for the development of any nation. Empowerment is mostly about taking control of one's own life, setting their own agenda and taking their own decisions (Thanavanthi, 2018). Empowerment is building confidence of the women in their own capacities. It's a multi-dimensional human process that may either be political, whereby women have complete freedom to participate within the political field, contest elections or hold any workplace of power, or it are often economic, wherein women have financial independence and access and control of financial resources or it can be social, wherein, there is an overall transformation in the society and women have full freedom in all aspects of life. An empowered women is the backbone of the country.

\section{THE IMPACT OF SOCIAL MEDIA ON WOMEN EMPOWERMENT}

Why social media has become so important is mainly because of the ease of opening an account and its reach to the millions of people at a click of a button at almost no or negligible cost. It has become a medium for self-expression for the women. It has empowered women socially, psychologically and financially. It has enhanced the participation of women in the social, political and cultural fields. It has helped in the capacity-building of the women, which has in-turn encouraged their participation in the decision-making processes. The social media has given a new platform to the female ideologies. Due to the technological innovations, women issues have gained a Centre stage. It has become an information guide for the women that helps them connect to the outside world. The hashtag activism has helped women spread awareness regarding issues faced by them. One prominent example is of Manal-al-Sharif, who posted a video of herself driving in 2011. Through this video on YouTube and Facebook, she highlighted how a basic right like driving was denied to millions of girls in Saudi Arabia and across the globe. This led to a viral \#Women2Drive Movement across the world and eventually due to its influence, women were given the driving rights in Saudi in 2018. Another landmark example is of 2012 Delhi gangrape, wherein the agitation by different activists on several social media platforms compelled the authorities to take stringent actions and amend the laws at the earliest. In 2014, United Nations promoted \#HeforShe Movement by inviting men and members other genders to support women to ensure gender equality and end all forms of gender discrimination. \#knowyourLemons Campaign was also introduced in 2014 to spread awareness amongst women regarding breast cancer. In 2017, \#LahuKaLagaan Campaign was started by Mumbai based NGO, She Says India, to abolish the Goods and Services Tax on the sanitary pads and they even achieved success in 2018 when government made the sanitary napkins became tax free. In 2017-18, \#MeToo Movement gained worldwide momentum when prominent figures were accused of sexual assault and harassment. Many women have now started their own businesses through the medium of social networking sites as the investment required is very less. Many such ventures boomed during the lockdown.
Thus, the social media has been actively involved in encouraging the entrepreneurial skills of the women. It makes easy for the women to start new businesses, to market their products and to reach out a number of customers easily. There are several prominent women who have gained recognition because of their online businesses that were started or promoted on the social media platforms. Few examples being Aditi Gupta (Menstrupedia), Richa Singh (YourDost), Richa Kar (Zivame), Shradha Sharma (Yourstory.com), Sabina Chopra (Yatra.com) and Chhavi Mittal (Shitty Ideas Trending).

\section{IV.SHORTCOMINGS \& WHAT MUST TO BE DONE?}

We live in a very free and fair world where everyone has access to all the information, whether true or false. This age of social media has made the spread of information even easier. But the question remains that is this easy flow of information advantageous to all or is it having a negative impact. Social media on one hand is an important medium to empower women but on the flip side, is proving dangerous in certain aspects too. It has helped in democratizing the access to information but has also highlighted the major fault lines that are still prevalent. This has become an issue of major concern at the global, national and regional levels. The hashtag culture might be a powerful tool to empower women but at the same time it has been observed that it is being widely used to threaten women. Slut shaming and threatening of rape and murder by unknown accounts has become extremely common.

At times, excess transparency on social media can actually infringe upon the right to privacy of an individual. Also, the prevalence of so many hashtag movements cause a certain kind of activism fatigue and prevents the major movements from getting the required attention. Internet and social media platforms, that were earlier praised for creating an unbiased platform for marginalized narratives is now being misused by certain sections for promoting their motives of self-interest based on who pays the most. The recent technological innovations have enabled an unrestricted access to data and most of the citizens lack the ability to differentiate between correct information and fake news. In this power contest, the genuine voices get lost at times. While some groups tend to spread propaganda to manipulate public opinion through these tools, it is the real voices of real women which are ignored. Also, the increasing percentage of cyber-crimes are not unknown to anyone now.

These crimes pose a major threat to the security of the person and the victim becomes extremely vulnerable to the offences like hacking, morphing, online trolling, harassment, cyber-defamation, dark net, obscene websites, fake profiles, cyber bullying etc. The presence of a large amount of sexuallyexploitative content on the internet, poses further threat to the safety of women. Thus, it is the need of the hour to ensure that strict laws need to be made. IT Act 2000 needs to made stronger to tackle the increasing cases of cyber-crime. 
Lastly, digital divide is kind of evident in Bharat. Women within the rural areas don't have any access to net and so, cannot use any of the digital platforms. This issue has to be selfaddressed at the earliest. Google India and Tata Trusts in 2015 came along to begin an initiative to enhance digital literacy amongst women in rural areas. The net connectivity in the suburbs and rural areas got to be improved and women ought to be trained to use these facilities effectively.

\section{CONCLUSION}

Empowerment of the women is a basic human right that they have to be entitled to. Social media helps them tackle the new challenges display to them within the contemporary world. The use of these social media platforms should be encouraged to ensure that women rights can be advocated to the maximum extent. By facilitating the women's access to all these platforms and websites, it would ensure that all opportunities are available for all. So, despite all the backlash that social media receives, it can be said that a regulated media will really be a lot of useful than dangerous within the longer run.

\section{REFERENCES}

1. Marsh, David, Paul 't Hart and Karen Tindall (2010): "Celebrity Politics: The Politics of Late Modernity?' Political Studies Review, Issue 8, Vol 3, pp 322-40.

2. Natalie Fenton \& Veronica Barassi, (2011). Alternative Media and Social Networking Sites: The Politics of Individuation and Political Participation, The Communication Review, 14:3,179-196 http://dx.doi.org/10.1080/10714421.2011.597245

3. Sardesai, Rajdeep (2014): The Election that Changed India, London: Penguin

4. Amruth, $M$ (2007): "Silences and the Impossibility of Confabulation after Godhra," Economic \& Political Weekly, No 49, Vol 42, pp 23-25. 